\title{
Efektivitas Terapi Infeksi Helicobacter Pylori pada Anak dengan Keluhan Sakit Perut Berulang Setelah Satu Tahun Terapi Eradikasi
}

\author{
Tina Ramayanthi, Dwi Prasetyo, Herry Garna \\ Departemen Ilmu Kesehatan Anak Fakultas Kedokteran Universitas Padjadjaran/Rumah Sakit Dr. Hasan \\ Sadikin, Bandung
}

\begin{abstract}
Latar belakang. Infeksi Helicobacter pylori pada anak dapat menyebabkan beberapa penyakit, seperti gastritis, ulkus peptikum, dan kanker gaster. Sakit perut berulang (SPB) merupakan keluhan tersering terinfeksi $H$. pylori, terutama pada usia sekolah. Pada anak yang telah diberikan terapi eradikasi, respons pengobatan harus dipantau, salah satunya dengan pemeriksaan serologis antibodi IgG.

Tujuan. Mengetahui apakah telah terjadi perubahan status serologis IgG $H$. pylori satu tahun setelah terapi eradikasi pada anak dengan keluhan sakit perut berulang (SPB) pada yang terinfeksi H. pylori.

Metode. Penelitian dengan rancangan cross sectional periode Juli-September 2011 yang dilakukan pada siswa anak usia 6-18 tahun di beberapa SD, SMP, atau SMA di kota Bandung. Subjek dengan keluhan sakit perut berulang dengan status serologis IgG $H$. pylori positif sebelum diberikan terapi dan telah diberikan terapi eradikasi satu tahun yang lalu. Uji Exact Fisher digunakan untuk analisis data.

Hasil. Tigapuluh empat anak memenuhi kriteria inklusi. Semua anak memperlihatkan perubahan serologis IgG $H$. pylori menjadi negatif. Terdapat 4 anak yang masih mengalami gejala SPB, dan 30 anak tidak terdapat gejala SPB setelah terapi eradikasi (Prevalensi 11,8\%, IK: 4,7-26,6).

Kesimpulan. Status serologis IgG $H$. pylori semuanya negatif, setelah satu tahun selesai terapi eradikasi pada anak dengan keluhan sakit perut berulang. Sari Pediatri 2013;15(2):111-5.
\end{abstract}

Kata kunci: $\operatorname{IgG} H$. pylori, sakit perut berulang, terapi eradikasi

$\mathrm{I}$ nfeksi $H$. pylori pada anak mengenai sekitar $80 \%$, terutama anak di bawah usia 10 tahun. Di negara maju, infeksi $H$. pylori pada anak sekitar $10 \%$, dan $50 \%$ anak tersebut hidup dalam lingkungan

Alamat korespondensi:

Dr. Tina Ramayanthi. Departemen Ilmu Kesehatan Anak Fakultas Kedokteran Universitas Padjadjaran/ RS dr. Hasan Sadikin, Jl. Pasteur 38 Bandung 40163, Telp. (022) 2035957, Fax. (022) 2034426. E-mail: kireinatina@yahoo.co.id sosioekonomi yang rendah. Infeksi $H$. pylori pada umumnya bersifat asimtomatik, dan sekitar 10\%-15\% akan menimbulkan beberapa penyakit, seperti gastritis, ulkus peptikum dan dalam jangka panjang dapat menyebabkan adenokarsinoma gaster serta mucosa associated lymphoid tissue lymphoma (MALT lymphoma), anemia defisiensi besi, bahkan pada anak dapat menyebabkan gangguan pertumbuhan. ${ }^{1}$

Sakit perut berulang (SPB) apabila didapatkan tiga episode sakit perut berat yang menyebabkan 
terganggunya aktivitas sehari-hari selama periode tiga bulan atau lebih. Salah satu penyebab tersering sakit perut berulang pada anak adalah infeksi $H$. pylori. $^{2}$ Tujuan pengobatan infeksi $H$. pylori untuk eradikasi bakteri di dalam perut. Berdasarkan Consensus Conference on the Management of H. pylori Infection, pada anak infeksi $H$. pylori yang telah diterapi, respons terhadap pengobatan harus dipantau 4 minggu setelah terapi eradikasi. ${ }^{3}$ Tes serologis terbukti merupakan pemeriksaan yang akurat untuk monitoring pengobatan, tetapi pemeriksaan tersebut membutuhkan waktu lebih lama, yaitu sekitar 6 bulan atau lebih untuk mengetahui keberhasilan terapi eradikasi. ${ }^{4,6}$ Pada penelitian sebelumnya dengan menggunakan pemeriksaan serologis secara kualitatif pemberian terapi eradikasi pada penelitian tersebut tidak efektif. $^{5}$

Pemantauan setelah terapi eradikasi dengan metode serologis masih jarang dilakukan di Indonesia, terutama dengan menggunakan antigen lokal. Pada penelitian ini, kami bermaksud untuk mengetahui apakah terdapat perubahan serologis antibodi $\operatorname{IgG}$ pada anak dengan keluhan SPB yang terinfeksi $H$. pylori setelah satu tahun terapi eradikasi dengan teknik immunochromatographic test (ICT) memakai antigen lokal produksi Laboratorium Bio Medika Mataram.

\section{Metode}

Penelitian observasional dengan rancangan cross sectional (selective prevalence) yang dilaksanakan sejak bulan Juli sampai dengan September 2011. Subjek adalah subjek penelitian Prasetyo, ${ }^{7}$ yaitu anak usia 6 sampai 18 tahun siswa di beberapa SD, SMP, atau SMA di kota Bandung dengan keluhan SPB yang mempunyai status serologis positif terhadap infeksi $H$. pylori sebelum diberikan terapi. Subjek telah diberikan terapi antimikroba, yaitu amoksisilin dan metronidazol selama 2 minggu, serta omeprazol selama 4 minggu, kemudian dievaluasi satu tahun setelah selesai terapi eradikasi. Kriteria eksklusi, yaitu pindah tempat tinggal keluar dari kota Bandung.

Peneliti mendatangi tempat subjek bersekolah atau tempat tinggal subjek bersama petugas laboratorium. Subjek penelitian telah mendapat persetujuan dari orangtua untuk ikut dalam penelitian (informed consent). Terhadap subjek penelitian dilakukan pencatatan kembali nama, usia, jenis kelamin, status gizi, dan kelu- han mengenai SPB. Setiap subjek penelitian diambil darah $4 \mathrm{~mL}$, kemudian darah dibawa ke laboratorium Prodia untuk pemeriksaan serologis $H$. pylori dengan teknik immunochromatographic test (ICT) memakai antigen lokal produksi Laboratorium Bio Medika Mataram.

Variabel penelitian berjenis nominal, perhitungan besarnya risiko dengan rasio prevalens (95\% IK). Analisis data yang digunakan adalah uji Exact Fisher. Penelitian mulai dilaksanakan setelah mendapat persetujuan Komite Etik Penelitian Kesehatan Fakultas Kedokteran Universitas Padjadjaran/Rumah Sakit Dr. Hasan Sadikin Bandung.

\section{Hasil}

Pada penelitian kami, dari 107 subjek penelitian Prasetyo $^{7}$ hanya 34 anak yang diikutsertakan dalam penelitian, sementara 60 anak tidak diikutsertakan karena pindah tempat tinggal keluar kota Bandung, dan 13 anak menolak untuk ikut penelitian. Tigabelas anak laki-laki dan 21 anak perempuan ikut serta dalam penelitian ini. Secara statistik, semua karakteristik baik jenis kelamin, usia, dan penghasilan orangtua pada kedua kelompok dengan gejala SPB maupun yang tidak terdapat gejala SPB, tidak menunjukkan perbedaan bermakna ( $>0,05)$, kecuali status gizi yang memiliki perbedaan bermakna $(\mathrm{p}=0,036)$ (Tabel 1$)$.

Tigapuluh empat anak yang telah mendapat terapi eradikasi dilakukan pemeriksaan IgG $H$. pylori setelah satu tahun selesai terapi, dan terjadi perubahan serologis IgG $H$. pylori menjadi negatif. Empat anak masih mengalami gejala SPB, dan 30 anak tidak terdapat gejala SPB (Prevalensi 11,8\%, IK: 4,7-26,6).

\section{Pembahasan}

Pada penelitian kami, anak usia 6-18 tahun dengan gejala SPB diberikan dua macam antimikroba, yaitu amoksisilin dan metronidazol selama dua minggu, serta omeprazol selama 4 minggu. Hasil pemantauan satu tahun hingga satu tahun 6 bulan setelah terapi eradikasi, keluhan SPB tidak didapatkan lagi pada 30 orang anak. Semua anak (34 orang) menunjukkan perubahan status serologis IgG $H$. pylori menjadi negatif. Hal tersebut menandakan bahwa terapi menggunakan regimen dua macam antimikroba ditambah proton- 
Tina Ramayanthi dkk: Efektivitas terapi infeksi $H$. pylori dengan keluhan sakit perut berulang

Tabel 1. Karakteristik subjek penelitian

\begin{tabular}{lccc}
\hline Karakteristik & \multicolumn{2}{c}{ Jumlah } & \multirow{2}{*}{$\mathrm{p}^{*}$} \\
\cline { 2 - 3 } & Gejala SPB (+) & Gejala SPB (-) & \\
\cline { 2 - 3 } & $\mathrm{n}$ & $\mathrm{n}$ & 0,502 \\
Jenis kelamin & 1 & 12 & \\
$\quad$ Laki-laki & 3 & 18 & \multirow{2}{*}{0,397} \\
$\quad$ Perempuan & & & \\
Usia (tahun) & 1 & 14 & 0,036 \\
$\quad$ 6-14 & 3 & 16 & \\
$\quad$ 15-18 & & & \\
Status gizi & 2 & 28 & 0,403 \\
$\quad$ Baik & 1 & 2 & \\
$\quad$ Malnutrisi ringan & 1 & 0 & \\
$\quad$ Malnutrisi berat & & & \\
Pendapatan orangtua & 3 & 19 & \\
$\quad$ Rendah & 0 & 3 & \\
$\quad$ Sedang & 1 & 3 & \\
$\quad$ Tinggi & & & \\
\hline
\end{tabular}

*Uji Exact-Fisher, hubungan bermakna jika p<0,05; SPB: sakit perut berulang

pump inhibitor mempunyai hasil yang sangat baik terhadap eradikasi infeksi $H$. pylori.

Penelitian sebelumnya menyatakan bahwa antara waktu 1 hingga $5 \frac{1}{2}$ bulan setelah pengobatan $H$. pylori didapatkan penurunan kadar titer IgG lebih dari $50 \%$ dibandingkan dengan kadar titer IgG sebelum pengobatan. ${ }^{4,6}$ Hasil penelitian kami sesuai dengan penelitian sebelumnya yang melaporkan pada anak yang terinfeksi $H$. pylori dengan pemeriksaan serologis antibodi IgG satu tahun setelah terapi eradikasi, didapatkan perubahan status serologis. ${ }^{5}$

Sakit perut berulang pada anak, selain disebabkan oleh infeksi $H$. pylori juga dapat disebabkan, antara lain organ gastrointestinal (konstipasi kronik, infeksi parasit, intoleransi laktosa, gastro-esophageal reflux disease, celiac disease, ulkus peptikum, gastritis, dispepsia fungsional, apendisitis kronik, pankreatitis kronik, irritable bowel syndrome, abdominal migraine, dan aerofagia), penyebab traktus urinarius (infeksi traktus urinarius, pelvic ureteric junction obstruction), penyebab ginekologi (kista ovarium, endometriosis, penyakit inflamasi pada pelvis), serta penyebab lain, seperti abdominal epilepsi dan stres emosional. ${ }^{2}$

Pada penelitian kami, 4 anak masih mengalami gejala SPB, satu di antaranya kemungkinan disebabkan karena TB abdomen. Pada ketiga subjek penelitian lain yang masih mengalami keluhan SPB, setelah dilakukan pemeriksaan oleh peneliti didapatkan rasa sakit yang menetap atau berulang atau rasa tidak nyaman, terutama di daerah perut bagian atas (di atas umbilikus), sedangkan pemeriksaan fisis lain masih dalam batas normal. Pada ketiga subjek tersebut, apabila keluhan disebabkan oleh infeksi $H$. pylori seharusnya gejala akan menghilang setelah pemberian terapi eradikasi. Hal tersebut sesuai dengan penelitian yang dilakukan oleh Uc dan Chong ${ }^{8}$ yang menyatakan bahwa pengobatan infeksi $H$. pylori dapat mengurangi gejala dispepsia. Pada ketiga subjek penelitian kami tidak terdapat reinfeksi $H$. pylori, terbukti dengan status serologis IgG $H$. pylori memiliki hasil negatif. Diperlukan pemeriksaan lanjutan untuk mengetahui penyebab gejala SPB. Hal tersebut menunjukkan bahwa gejala SPB pada 4 anak tersebut kemungkinan tidak disebabkan oleh infeksi $H$. pylori.

Status gizi mempunyai hubungan yang bermakna terhadap kejadian SPB satu tahun setelah selesai terapi eradikasi $(\mathrm{p}=0,036)$. Berdasarkan penelitian sebelumnya, terdapat pendapat yang berbeda mengenai pengaruh infeksi $H$. pylori pada gangguan pertumbuhan dan malnutrisi. Windle $\mathrm{dkk}^{9}$ berpendapat bahwa infeksi $H$. pylori pada anak di negara sedang berkembang merupakan inisiator terjadinya lingkaran setan malnutrisi dan gangguan pertumbuhan. Infeksi akut $H$. pylori akan menyebabkan hipoklorhidria akibat gangguan barier asam lambung. Interleukin IL-1 $\beta$ merupakan supresor asam lambung yang poten dan polimorfism dalam kluster gen IL-1 akan memproduksi lebih banyak IL$1 \beta$ sehingga merupakan inisiator terjadinya lingkaran 
setan malnutrisi dan gangguan pertumbuhan. Pada penelitian Soylu dan Ozturk ${ }^{10}$ didapatkan anak dengan keluhan dispepsia dengan atau tanpa infeksi $H$. pylori mempunyai status gizi kurang dibandingkan dengan kelompok anak tanpa keluhan dispepsia. Hal tersebut disebabkan anak dengan keluhan dispepsia mempunyai asupan kalori yang lebih sedikit dibandingkan dengan anak tanpa keluhan dispepsia. Berbeda dengan Husaini dkk, ${ }^{11}$ di Bogor, didapatkan hubungan bermakna antara stunting (defisit tinggi badan dibandingkan dengan usia) dengan infeksi $H$. pylori, tetapi tidak didapatkan hubungan bermakna infeksi $H$. pylori dengan underweight dan wasting.

Pada penelitian kami, satu anak mempunyai keluhan SPB dengan status gizi malnutrisi berat, satu anak dengan malnutrisi ringan, dan dua anak dengan status gizi baik. Secara statistik, status gizi merupakan faktor risiko bermakna timbulnya kembali gejala SPB pada anak yang telah mendapat terapi eradikasi. Namun, perlu ditelaah lebih lanjut apakah penyebab malnutrisi ini hanya disebabkan oleh infeksi $H$. pylori, ataukah terdapat penyebab lain. Setelah dilakukan anamnesis dan pemeriksaan fisis oleh peneliti pada saat pengambilan sampel, ternyata satu anak dengan status gizi malnutrisi berat tersebut dicurigai menderita TB abdomen, sehingga disarankan untuk pemeriksaan dan pengobatan lanjutan. Penelitian Prasetyo, ${ }^{7}$ sebelum mendapat terapi eradikasi anak tersebut mempunyai status gizi malnutrisi berat, dan pada penelitian kami setelah didapat terapi eradikasi masih menunjukkan keluhan SPB dan tidak ada perbaikan. Kemungkinan pada penelitian kami, status gizi tidak berhubungan dengan keluhan SPB pada anak yang telah mendapat terapi eradikasi tersebut.

Berdasarkan penelitian sebelumnya, didapatkan pendapat yang berbeda mengenai pengaruh usia pada kejadian SPB setelah diberikan terapi eradikasi. Penelitian Magista $\mathrm{dkk}^{12}$ dan Rowland $\mathrm{dkk}^{13}$ menyatakan bahwa usia merupakan faktor risiko kejadian SPB setelah mendapat terapi eradikasi. Pendapat berbeda dikemukakan oleh Najafi $\mathrm{dkk}^{14}$ dan Thong-Ngam ${ }^{15}$ yang menyatakan bahwa usia tidak berpengaruh pada kejadian SPB pada anak yang telah mendapat terapi eradikasi. Pada penelitian kami, usia bukan merupakan faktor risiko terjadinya SPB setelah terapi eradikasi.

Tujuan terapi eradikasi $H$. pylori untuk mengeradikasi bakteri dari saluran cerna. Beberapa penelitian telah dipublikasikan untuk membandingkan efektivitas berbagai regimen dalam eradikasi $H$. pylori. $^{3}$

Penelitian kami memiliki keterbatasan apabila dibandingkan dengan metode non-invasif lain, seperti urea breath test, dan $H$. pylori stool antigen. Pemeriksaaan urea breath test dan $H$. pylori stool antigen mempunyai akurasi yang lebih baik dalam mengonfirmasi eradikasi infeksi $H$. pylori apabila dibandingkan dengan metode serologis. Keterbatasan penelitian kami pada jumlah subjek penelitian hanya 34 anak sementara 60 anak tidak diikutsertakan dalam penelitian. Seharusnya dilakukan pemantauan mengenai keluhan SPB dengan cara mengirimkan lembar pemantauan yang dikirimkan melalui surat. ${ }^{16,17}$

Pada penelitian kami, digunakan metode serologis secara kualitatif karena pemeriksaan serologis cukup valid untuk memantau efektivitas terapi dengan cara melihat perubahan status serologis pada anak yang telah mendapat terapi eradikasi.

\section{Kesimpulan}

Didapatkan perubahan status serologis IgG $H$. pylori dari positif menjadi negatif pada anak dengan keluhan SPB setelah satu tahun selesai terapi eradikasi.

\section{Daftar pustaka}

1. Das JC, Paul N. Epidemiology and pathophysiology of Helicobacter pylori infection in children. Indian J Pediatr 2007;74:287-90.

2. Devanarayana N, Rajindrajith S, de Silva H. Recurrent abdominal pain in children. Indian Pediatr 2009; 46:38999.

3. Malfertheiner P, Megraud F, O'Morain C. Current concepts in the management of Helicobacter pylori infection: the Maastricht III Consensus Report. Gut 2007;56:772-81.

4. Laheij R, Witteman E, Bloembergen P, de Koning R, Jansen J, Verbeek L. Short term follow-up by serology of patients given antibiotic treatment for Helicobacter pylori infection. J Clin Microbiol 1998;36:1193-6.

5. Kist M, Strobel S, Kirchner T, Dammann H. Impact of ELISA and immunoblot as diagnostic tools one year after eradication of Helicobacter pylori in a multicentre treatment study. FEMS Immunol Med Microbiol 1999;24:239-42.

6. Gisbert J, Blanco M, Benito L, Pajares J. Value of 
quantitative serology for confirmation of Helicobacter pylori eradication: an 18 month follow up study. Clin Infec Dis 2000;30:976-80.

7. Prasetyo D. Sistem skoring untuk memprediksi infeksi Helicobacter pylori pada anak usia 6-18 tahun dengan keluhan sakit perut berulang (Disertasi). Bandung: Pascasarjana UNPAD, 2010.

8. Uc A, Chong K. Treatment of Helicobacter pylori gastritis improves dyspeptic symptoms in children. J Ped Gastroenterol Nutr 2002;34:281-5.

9. Windle H, Kelleher D, Crabtree J. Childhood Helicobacter pylori infection and growth impairment in developing countries: a vicious cycle?. Pediatrics 2007;119:754-9.

10. Soylu O, Ozturk Y. Helicobacter pylori infection: effect on malnutrition and growth failure in dyspeptic children. Eur J Pediatr 2008;167:557-62.

11. Husaini M, Husaini Y, Suwardi S, Salimar, Widodo Y, Kurpad A, dkk. Relationship of Helicobacter pylori infection with diarrhea and nutritional status among nutritionally-at-risk children. World J Nucl Med 2005;4:165-73.

12. Magista AM, Ierardi E, Castellaneta S, Miniello VL,
Lionetti E, Francavilla A, dkk. Helicobacter pylori status and symptom assessment two years after eradication in pediatric patients from a high prevalence area. J Pediatr Gastroenterol Nutr 2005;40:312-8.

13. Rowland M, Kumar D, Daly L, O'connor P, Vaughan D, Drumm B. Low rates of Helicobacter pylori reinfection in children. Gastroenterol 1999;117:336-41.

14. Najafi M, Sobhani M, Khodadad A, Farahmand F, Motamed F. Reinfection rate after successful Helicobacter pylori eradication in children. Iran J Pediatr 2010;20:5862.

15. Thong-Ngam D. Incidence of Helicobacter pylori recurrent infection and associated factors in Thailand. J Med Assoc Thai 2007;90:1406-10.

16. Muttaqin Z SD, Gunawan S, Soemohardjo S. Laporan penelitian: pengembangan kit dignostik cepat untuk mendeteksi antibodi Helicobacter pylori (ICT) menggunakan antigen lokal. Mataram: Unit Riset Biomedik RSU Mataram; 2004.

17. Vaira D, Vakil N, Menegatti M, van't Hoff B, Ricci C, Gatta L, dkk. The stool antigen test for detection of Helicobacter pylori after eradication therapy. Ann Intern Med 2002;136:280-7. 